\title{
A WMSTIARDA MIDR
}

BDITRANGE ZUUR

\section{A LTIDRDN}

GDRMIAMISTIIK

Band 51 


\title{
THE LOSS OF OLD FRISIAN $H$ IN INITIAL CONSONANT CLUSTERS ${ }^{1}$
}

\author{
by Han Nijdam - Amsterdam
}

\section{Introduction}

Old Frisian (OFri), its manuscript tradition beginning in the late 13th century and ending roughly in the middle of the 16th, is the youngest of the Old Germanic languages. This, however, does not mean that it does not show some interesting features, which sometimes can even be said to be archaic or conservative. One of those features is the loss of $h$ in the initial consonant clusters \#hl-, \#hn-, \#hr-, or shorter \#hR-. 2 Whereas in languages like Old Dutch (ODu) and Old Saxon (OS) these clusters had already been reduced to $\# l$-, \#n- and \#r- in the course of the 10th and 11th centuries, this process did not take place in OFri until the 15th and 16th centuries. This makes OFri the last of the Germanic (Gmc) languages to 'drop its aitches' in this position, with the exception of Icelandic, which has retained them until this day. In the following, I will describe the process for OFri.

\section{Old Frisian}

Old Frisian has come down to us in a group of codices and charters written in this language. The oldest manuscripts stem from the end of the 13th century, with perhaps a small fragment of psalm glosses which might be dated to around 1200 preceeding them (see below). OFri comes to an end in the course of the 16th century, when the last charters and letters are written in it. Then Dutch (Du) becomes the language used in these documents. After a short interval in which almost nothing is written in Frisian (Fri), Gysbert Japicx writes his works in what is called Middle Frisian in the 17th century.

OFri forms part of the group of so-called North Sea Germanic (NSGmc) languages, together with Old English (OE) and OS. NSGmc is a set of language features, shared by OE, OFri, and to a lesser extent, OS and Dutch. Some of these features are: loss of nasal $(\mathbf{N})$

1 This article is based on my graduate paper 'Oudfries $h$ in de combinaties \#hl-, \#hn- en \#hr-' (Old Germanic languages and cultures, University of Amsterdam).

${ }^{2} \mathrm{R}=$ resonant $(l, n, r)$. For this notation see e.g. H. H. Hock, Principles of historical linguistic, Berlin etc. 1986, 31. 
with compensatory lengthening before homorganic spirant; palatalization of velar consonants $(\mathrm{C})$; uniform plural ending in present and preterite indicative. ${ }^{3}$ There has been a long and ongoing debate roughly about whether the Angles, Saxons and Jutes moving to England in the 5th century were already speaking 'Proto NSGmc', whether NSGmc arose in England a few centuries later, came back via Frisia (as a result of the extensive Frisian trade along the North Sea coast in those days) and reached the Saxons who were still living in Germany only partially and late, or whether we are dealing with a 'Ingvaeonic branch-cumdialect continuum of West Germanic. '4.

Fragmentary information about Frisian from the period before the OFri manuscripts can be gained from a few sources: Frisian runic inscriptions (5/6th-9th century), some 20 in all.5; a number of words in the socalled Lex Frisionum (ca. 802), which are possibly Frisian ${ }^{6}$; and some Frisian words in charters (9th-12th century). ${ }^{7}$ These data, together with archaeological (different funerary customs) ${ }^{8}$ and sociopolitical evidence (war with the Franks), all hint at the emergence of Frisian as an independent Germanic language in the 8th century.

OFri proper is divided into two dialect groups, Old East Frisian (OEFri) and Old West Frisian (OWFri) ${ }^{9}$, the boundary being the river

3 P. V. Stiles, 'Remarks on the "Anglo-Frisian" Thesis', in: V. F. Faltings et al. (eds.), Friesische Studien II. Beiträge des Föhrer Symposiums zur Friesischen Philologie vom 7.-8. April 1994, Odense 1995, 177-220; 178.

${ }^{4}$ Stiles, 'Remarks on the "Anglo-Frisian" Thesis', 211; see also S. Krogh, Die Stellung des Altsächsischen im Rahmen der germanischen Sprachen (Studien zum Althochdeutschen 29), Göttingen 1996.

${ }^{5}$ T. Looijenga, 'Checklist Frisian runic inscriptions', in: T. Looijenga en A. Quak (eds.), Frisian runes and neighbouring traditions. Proceedings of the first international symposium on Frisian runes at the Fries Museum, Leeuwarden 26-29 january 1994 (= ABäG 45), Amsterdam 1996, 91-108.

${ }^{6}$ H. H. Munske, Die germanische Rechtswortschatz im Bereich der Missetaten. Philologische und sprachgeografische Untersuchungen. I. Die Terminologie der älteren westgermanischen Rechtsquellen, Beriin/New York 1973, 107.

${ }^{7}$ M. Gysseling, 'Het Oudste Fries', in: It Beaken 24 (1962), 1-26, and M. Gysseling, 'Chronologie van enkele klankverschijnselen in het oudste Fries', in: K. Dykstra et al. (eds.), Fryske stúdzjes, oanbean oan prof. dr. J.H. Brouwer op syn sechstichste jierdei 23 augustus 1960, Assen 1960, 77-80.

8 E. Knol, De Noordnederlandse kustlanden in de vroege middeleeuwen, Groningen 1993, 242-243.

${ }^{9}$ For a description of the manuscripts belonging to either of these dialects, see below. 
Lauwers, now between the Dutch provinces of Friesland and Groningen. OEFri has come down to us in manuscripts from the 13th-15th century; the OWFri tradition starts a little later, in the 15th, and continues into the 16th century. In 1966 this old division in dialectal branches was criticized by Sjölin, who argued that the differences between OEFri and OWFri were differences in time, not in place. Furthermore, OWFri had adopted a different graphematical system, along with the introduction of Roman and canon law. Therefore, he opted for the terms Classical OFri and Post-classical OFri, and he put the large corpus of charters written in OWFris into a separate category, calling it 'charterlanguage' ('Urkundensprache'). 10

Since 1966, different scholars have investigated the problem, and proved that there are indeed phonological ${ }^{11}$, lexicological ${ }^{12}$ and morphological ${ }^{13}$ differences between OEFri and OWFri, which make the dialect division fully warranted. In fact, as we shall see below, loss of Old Frisian $h$ in initial consonant clusters will reveal a further difference between OEFri and OWFri.

The only point Sjölin made which still stands, is the fact that the existant manuscripts, like the First and Second Riustring manuscripts (R1 and R2) and the three Emsing manuscripts (E1, E2, E3), are compilations, containing private collections of different, partly 'panFrisian', legal texts, and do not constitute the law of a certain district. This last notion was fashionable before Sjölin's 1966 article and was fed by the titles of the individual volumes of the Altfriesische Rechtsquellen series, edited by Buma and Ebel, like Das Rüstringer Recht or Das Brokmer Recht. ${ }^{14}$

\section{Old Frisian $\boldsymbol{h}$ in initial consonant clusters}

As already stated, the subject of this article is the loss of OFri $h$ in the

10 B. Sjölin, 'Zur Gliederung des Altriesischen', in: Us Wurk 15 (1966), 25-38.

11 D. Hofmann, 'Die Sprache der Fivelgoer Handschrift und die Gliederung des Altfriesischen', in: Studia Neophilologica 43 (1971), 352-374.

12 Munske (see n. 6).

${ }^{13}$ H. D. Meijering, 'Die altfriesischen monosyllabischen Infinitive auf $\boldsymbol{n} \boldsymbol{n}$ und die Gliederung des Altfriesischen', in: R. H. Bremmer et al. (eds.), Aspects of Old Frisian Philology (= ABäG 31/32), Amsterdam 1990, 336-348.

14 W. J. Buma and W. Ebel, Das Rüstringer Recht (Altfriesische Rechtsquellen 1), Gôttingen 1963; W. J. Buma and W. Ebel, Das Brokmer Recht (Altfriesische Rechtsquellen 2), Göttingen 1965. I personally suspect that this series may have been one of the incentives for Sjölin to write his article. 
initial consonant cluster \#hR-. In the following I will give and analyse the evidence for this process in OFri, first for OEFri, then for OWFri; I will finally sketch the process for the entire OFri area. I will also try to explain the loss by attempting to reconstruct the sound values of OFri $h, l, n$, and $r$.

For my analysis, I gathered token level evidence from all OFri manuscripts we know of today, and stored them in a database. This resulted in a file containing 2792 records. While collecting the material I met with a number of difficulties. First, there is no conclusive dictionary of OFri to date. This meant that I was running the risk of encountering OFri forms whose headwords had not yet been described. This indeed turned out to be the case: I found 39 OFri words which had no entries in Holthausen and Hofmann's dictionary ${ }^{15}$. I must add that for the most part they were compounds of known simplexes. The bulk of these 'new' forms stems from the charters, which not only make up 53\% of my entire OFri corpus, but which have been edited without glossaries, which makes them rather inaccessible.

In the second place, it is not only the charters which lack glossaries. There are other manuscripts, like the OWFri codex Aysma, which have been edited without one. Moreover, some OWFri manuscripts do not even exist in any a modern edition (see below). This problem could, however, be resolved by consulting the so-called 'Oudfries Woordenboekapparaat' at the Frisian Institute in Groningen: a collection of glossaries on all OFri manuscripts, arranged on index cards.

The harvest of my collecting work can be seen in the appendix. In that list, I opted for a rather archaic or OEFri orthography; also provided all headwords (types) with an \#h-, although for some of them all actual forms (tokens) had already lost it. The evidence in those cases was from the etymology of the headwords.

The combination \#hw- was excluded from the present study for three reasons. First, it has not definitely been ascertained wether $h w$ is a single phoneme or two ${ }^{16}$. Secondly, until the last spelling innovation in Modern Fri (ModFri), 'who' was still written $h w a$, while the $h$ was definitely lost in the other clusters. Third, there is the matter of quan-

15 F. Holthausen and D. Hofmann, Alffriesisches Wörterbuch. $2 \mathrm{~d}$ ed., Heidelberg 1985. See also the appendix: the words which have been marked with + are not in Holthausen and Hofmann.

16 W. G. Moulton, 'The Proto-Germanic non-syllabics (consonants)', in: F. van Coetsem and H.L. Kufner (eds.), Toward a grammar of Proto-Germanic, Tübingen 1972, 141-173, 143. 
tity. Not only are there quite a number of words beginning with \#hwin OFri, they are also very frequent, like the pronoun hwa ' who'. Had I also collected this material, my database would have been double or perhaps even triple the size, thereby exceeding my possibilities at the time I was doing my research.

\section{Old East Frisian}

The following manuscripts contain texts in OEFri ${ }^{17}$ : the first Brokmer manuscript (B1; \pm 1280 ), the second Brokmer manuscript (B2; 1345), the first Riustring manuscript $(\mathrm{R} 1 ; \pm 1300)$, the second Riustring manuscript (R2; 1327), the third Riustring manuscript (R3; fragment; ?), the fourth Riustring manuscript (R4; fragment; \pm 1300 ), the first Hunsingo manuscript $(\mathrm{H1} ; \pm 1300)$, the second Hunsingo manuscript ( $\mathrm{H} 2 ; \pm 1300$ ), the third Hunsingo manuscript ( $\mathrm{H} 3$; fragment; ?), the first Emsing manuscript (E1; \pm 1400 ), the second Emsing manuscript (E2; \pm 1450$)$, the third Emsing manuscript (E3; \pm 1450$)$, the Fivelgo manuscript ( $\mathrm{F} ; \pm 1450$ ), the psalm glosses (PS; 1200?), OEFri charters (a total of 4; OO; toward 1400). Of these, only $\mathrm{H} 3$ and two OEFri charters contain no words with \#hR-.

All OEFri manuscripts have come to us in their original form, except for R2, which is now lost, but was copied at the end of the 18 th century by G. Oelrichs. We know the exact year of the original because the scribe dated it at the end of his work: Sit tibi tale vale michimet desidero quale. Anno domini MCCC XXVIJ in die Thome apostoli 'I wish you well, and I hope I will be too. In the year of our Lord 1327 on the day of the apostle Thomas [ $=$ december 21$]^{18}$.

On the dating of the OEFri psalm glosses, which have come down to us written on a piece of parchment that contains fragments of the Latin psalms 17 and 28 with an OFri translation, much had been said already. The latest editor of the fragments, Langbroek, only gives an overview of the different datings, which range from the 11th to the 13 th century ${ }^{19}$. I can only add that if the glosses were indeed from the 11 th century, I would sooner have expected a form *behrorith rather

17 For editions, see R. H. Bremmer, A bibliographical guide to Old Frisian studies, Odense 1992.

18 R2,VIII,62-64 ( $=$ R2, text VIII of the edition, lines 62-64), edited by: W. J. Buma (ed.), Het tweede Rüstringer handschrift (OTR 8), The Hague 1954, 71.

19 E. Langbroek, 'Condensa atque tenebrosa. Die altfriesische Psalmen: Neulesung und Rekonstruktion (UB Groningen Hs 404)', in: R. H. Bremmer et al. (eds.), Aspects of Old Frisian philology (= ABäG 31/32), Amsterdam 1990, 255-284. 
than berorith as we find it in the text, which I will enlarge upon below. However, even if the psalms are to be dated to the 13th century, they are in all probability our oldest bits of OFri.

\section{Old West Frisian}

OWFri is found in the following manuscripts: Codex Unia (U; \pm 1475 ); Codex Roorda (Ro; \pm 1480 ); the incunable 'Freeska Landriucht' or '(Oude) Druk' ('Old Printing'; D; \pm 1485 ); Codex Aysma (A; \pm 1500 ), Codex Parisiensis ( $\mathrm{P} \pm 1500)$; Codex Jus Municipale Frisonum (J; \pm 1530$)$; Codex Furmerius (FS). Besides these codices, which contain collections of texts comparable to the OEFri ones, we have the texts Foertgongh des gastelika riuchtes (E4; 1457); the Basel Wedding Sermons (BT; 1445); the 'Snitser Recesboeken' ('Police registers of the city Sneek'; SR; 1490-1517); a few hundred charters (O1234; 1329-1573 [but bulk: 1450-1525]); some letters (FB); the 'Leeuwarder Stedstiole' ('Police registers of the city Leeuwarden'; LS; 1502-4); the chronicle Thet Freske Riim (FR; 1490); a compilation of chronicles in Ms. Leeuwarden RA. Schw. 3992 (LR; 1525); a compilation of chronicles in Ms. Leeuwarden PB 362 Hs (LM; 1525); the so-called 'Annals of Edo Jongama' (EJ; 1525).

OWFri can in my view be divided into a three subgroups. First there are the collections of mainly legal texts, comparable to the OEFri manuscripts; U, J, D, A, Ro, P, Fs, and E4. These last three are of a somewhat different character than the first five, but contain or consist of roughly the same texts. All these manuscripts (except Fs) can be dated between 1450 and 1500 . A very large second subgroup is made up by the charters and other administrative documents: O1234, SR, BT, LS and FB. Thirdly, there is a small group of chronicles; FR, LR, LM and EJ. Together with a number of charters and SR, the last three of the chronicles inform us about OFri from the first quarter of the 16th century:

The OWFri tradition is much more heterogeneous than the OEFri, and it would go beyond the scope of this article to discuss the intricacies of the tradition of the different texts and manuscripts ${ }^{20}$. A few short remarks: Codex Unia is now lost, but is known from the transcripts and collations in a copy of D owned by Franciscus Junius

20 See a.o.: T. L. Markey, Frisian (Trends in linguistics 13), The Hague etc. 1981; P. Ramat, Das Friesische. Eine Sprachliche und kulturgeschichtliche Einführung (Innsbrucker Beiträge zur Sprachwissenschaft 14), Innsbruck 1976; B. Sjölin, Einführung in das Friesische (Sammlung Metzler), Stuttgart 1969. 
(1591-1677), which this humanist made in the 17th century. Nine copies of D were preserved to this day. Codex Parisiensis is a convolute, made up of four parts: legal texts from the province of Groningen, from the province of Drente, one of the nine copies of $D$, and finally a section with OFri texts, written as an addition to $D$. This last section was edited by Gerbenzon under the title 'Codex Parisiensis' in the Oudfriese Taal- en Rechtsbronnen series ${ }^{21}$. Codex Furmerius is a collection of transcripts of OFri texts that are now lost, made in the 17 th century by Bernard Furmerius.

Whereas all OEFri codices were published in the Oudfriese taal-en rechtsbronnen series (OTR), this fortunate fate did not befall the OWFri manuscripts. Although editions of U, D and Ro were planned, the series simply died out in the 1970's 22 .

\section{A few Old East Frisian lexicological problems}

Before giving the OFri evidence for the loss of $h$ in the cluster \#hR-, I will deal briefly with a few lexicological problems I encountered during my research.

First, there is hlotth in B12. The form <hlothe> appears three times in these manuscripts ${ }^{23}$. The question is whether we are dealing with the headword hloth 'band, group of people, company' as found in the standard dictionaries, or with the headword hlot 'lot, dice-game'. This last interpretation stems from Buma, who edited B12 twice 24 . To put it shorter, because of the arguments given by Rooth, who gives parallels from different Germanic dialects ${ }^{25}$, and because of the fact that we

21 P. Gerbenzon (ed), Codex Parisiensis (OTR 9), The Hague 1954.

22 See Munske (as n. 6) 96-7. From the overview given here by Munske we can deduce that $D, J, U, A$, Ro and Fs were planned as vols XIII - XVIII, respectively, of the series OTR. A printer's proof even exists of D, made by $\mathrm{K}$. Fokkema and E. Galama. Later J was published in the series Altfriesische Rechtsquellen (W. J. Buma and W. Ebel (eds.), Westerlauwerssches Recht I. Jus Municipale Frisonum (AR 6). 2 vols. Göttingen 1977) and later still A was published outside any series (W. J. Buma, P. Gerbenzon and M. TragterSchubert (eds.), Codex Aysma: die altfriesischen Texte, Assen/Maastricht 1993. Plans to publish U, D and Ro have been developed in recent times.

23 B1,43,17; B2,44,15; B2,44,15***; W.J. Buma (ed.), Die Brokmer Rechtshandschriften (OTR 5), The Hague 1949, 43 and 44.

24 See note 23 and: W. J. Buma en W. Ebel (eds.), Das Brokmer Recht (AR 2) Göttingen 1965.

25 E. Rooth, 'Westfäl. lout n. 'Menge, Schar (Kinder)' und seine Vorfahren', in: D. Hofmann (ed.), Gedenkschrift für William Foerste, Köln/Wien 1970, 167-176. 
find -th only in B12, whereas all OFri forms of hlot 'lot' show -t, I think that we are dealing with hloth 'band, group of people, company' (< PGmc *hlöthö-.

A more difficult problem is the form <hreclit> in H12. In a text of the so-called 'Hunsingo fines', we find:

Enre frowa hire thriu clathar thruch snithen. thet hreclit bi elleua scill.' thet mother bi thritega enzem. thet hemethe bi sogen mer. $\mathrm{kum}^{26}$. ('When the three layers of clothes of a woman are cut, [the. fine for cutting] the hreclit [is] eleven shillings, [for] the camisole thirty ounces, [for] the shirt seven marks').

Apparently, at the time the fines were written, Frisian women wore three layers of clothes, and <hreclir $>$ was the term for the outer gar ment. Like <hlote> in B12, <hreclit> is only found in $\mathrm{H} 12$ (the $\mathrm{H}$ texts, like the $B$ texts, are copies of one another), which makes the interpretation more difficult. Moreover, the form is rather difficult to etymologize. The problem is made more complex by the existence of a parallel in the text 'Vermischte Bestimmungen' (XVII) in F, where the outer garment is called <recklin>27, a form which at first sight looks like <hreclit>. Because of this superficial similarity and their ap pearance in parallel texts, they have been seen as forms of the same word.

Van Helten thought them both to be forms of OFri hreg 'back' + diminutive suffix -lin; he referred to Old High German (OHG) faistiling 'glove' < OHG fûst 'fist' and Middle High German (MHG) vingerlin 'ring' < MHG vinger 'finger'. This solution impelled him to assume faulty spelling in <hreclit>, and 'Auslautsverhärtung' from hreg to hrek-. Moreover, the suffix -lin is rather rare in OFri, and is more frequently found in the High and Low German area ${ }^{28}$.

Sjölin, taking $F$ as a starting-point, derives <recklin> from Middle Low Germ. (MLG) röcklin 'a type of outer clothes'. Because of the numerous MLG influences which can be detected in F, I think Sjölin is right in the case of <recklin $>$.

I think, however, that <recklin $>$ and $<$ hreclit $>$ are not the same word. First, if <hreclit> were a form of OFri reklin 'outer clothes', then the

${ }^{26}$ H12,IX, 170; J. Hoekstra (ed.), De eerste en tweede Hunsinger Codex (OTR 6) The Hague 1950, 73.

27 F,XVII,110; B. Sjölin (ed.), Die 'Fivelgoer' Handschrift I. (OTR 12) The Hague 1970, 354.

28 H. Krahe and W. Meid, Germanische Sprachwissenschaft III. Wortbildungslehre, Berlin 1969, 113. 
initial \#hr-would be hypercorrect, and the first of its kind, whereas the first hypercorrect forms actually appear in E23, dating from ca. 1450 , i.e. some 150 years later. Secondly, the word in F cannot be taken as solid proof, since there are other instances where words occur in $F$ in parallel texts, where they have the same appearance, but are of different origin. An example is the term <mother> in the above passage from H12. Here F has thet other cleth. Apparently the word mōther was no longer understood or in fashion at the time $F$ was written, and was replaced by something which looked somewhat like it, and meant approximately the same. Thirdly, I don't think we have to assume misspelling, because <hreclit $>$ can be explained as a form of hrēklēth, a compound of OFri hrē 'corpse' and klèth 'clothes'. In order to do this we have to account for only two things in the form $<$ hreclit $>$; the lack of final $-h$, and $<i>$ instead of $\bar{a}$ or $\bar{e}$ (OFri has both forms, kläth and klêth < PGmc *klaiða-). When we look at the entire orthography of $\mathrm{H} 12$, we find numerous instances where $-t$ is spelled for expected -th: <mit> for mith, <hebbat $>$ for hebbath, <nimat $>$ for nimath, etc. ${ }^{29}$. The spelling $<i>$ also turns out to be explainable. Van Helten points out a small number of instances where $<i>$ is written for expected $\bar{e}<$ PGmc $a i$, and that is exactly the sound we are dealing with here. So <hreclit $>$ can be explained without many problems as a spelling for OFri hréklēth. There is one little snag. As already mentioned, OFri hrē means 'ccorpse', as can be seen from OFri hrēräf "robbing a corpse, tomb-robbing' ${ }^{30}$, and it seems a little peculiar to call one's outer garment 'grave clothes'. Perhaps the use of hrēklêth referred to special burial customs?

About OEFri āghring (a compound of OFri àg 'eye' and hring 'ring, circle'), I can be short. It has always been translated as 'eyebrow', but I think it means 'eye-socket', or more precisely, 'the bone of the skull around the eye-socket'. First, OFri already has a word meaning 'eyebrow', āgbrē. Secondly, when we look at the passage where äghring is used, namely in the fines, we read that

"ef ther ene monne thi achring te breken is anderne tar nowet bi haIda ni mei sogen merk ${ }^{31}$. ("If a man has had his àghring broken, so that he cannot hold his tears, [he shall be compensated with]

${ }^{29}$ Hoekstra (as n. 26) 198, 189, 200. I leave aside the question whether this is a purely orthographical phenomenon or whether it should be explained phonologically.

30 Cf. also Munske (as n. 6), 171.

31 H12,VII,163/4; Hoekstra (as n. 26) 62. 
seven marks').

It would seem to me that an eyebrow is not something that can be broken, and that the damaging of it does not lead to such drastic changes in one's physiology as obviously the breaking of part of the skull can.

Finally, I encountered an OFri form which has not been satisfactorily explained yet, and to the solution of which I think I can add a little. The form occurs in E1, in a commentary to the second of the so-called '24 Statutes', a very wide-spread text. In a number of texts of the Statutes, this commentary has become part of the second Statute itself. The commentary deals with three causes why a widow can sell the property she administers for her underage child. The third cause deals with the situation in which the child is threatened with hunger and cold:

huuersa thet kind is stocknakad iefta huslas and thenna thiu thiustera nacht and thi neetkalda winter ur tha tuner hleth' ('When the child is stark naked or homeless and then the dark night and the cold winter $<$ hleth $>$ ( $3 \mathrm{pl}$.) over the acres').

We have a number of parallel texts. $\mathrm{H12}$, which contain Latin versions of some OFri texts, including then 24 statutes, have <descendit $>33$ 'to descend, come down upon'. In F we find $<$ hliet $>$ in stead of $<$ hleth>, from a rare verb OFri hlia 'to cover like a blanket' 34 , only found in $\mathrm{F}$ and in the OWFri codex $J$. This weak verb is derived form OFri hli 'protection, cover' (< PGmc. *hlewa- 'id.' < PGmc. *hlew'to be warm').

The solutions that have been given so far are: 1) < OFri *hleta 'dismount', cf. OE hlihtan ${ }^{35}$; a misspelling for <hlepth $><$ OFri urhlāpa 'to walk (over something)'36; 3) a misspelling for <hlieth $>$ analogous to the form in $\mathrm{F}^{37}$. None of these is really satisfying. First, there is no OE hlihtan, only lihtan ${ }^{38}$. Assuming misspellings seems to me an ulti-

32 E1,VIII,91; P. Sipma (ed.), De eerste Emsinger Codex (OTR 4) The Hague 1943.

33 H12,XVII, 33; Hoekstra (as n. 26) 91.

34 Holthausen and Hofmann (as n. 15) 45.

35 K. von Richthofen, Alffriesisches Wörterbuch. 1st ed.1840, Aalen 1970, 819.

36 H. Kern, 'Uit de Friesche wetten', in: Taalkundige Bijdragen 2 (1879), 171209.

37 W. L. van Helten, 'Zur Lexicologie und Grammatik des Altostfriesischen', in: $B G d S L, 14$ (1889), 232-87.

38 F. Holthausen, Altenglisches etymologisches Wörterbuch, Heidelberg 1934. 
mate resort, if no other solution can be found, and I do not think that we need assume one. Since OFri knê 'knee' shows the same sound changes ( $<$ PGmc *knewa-) as $h l \bar{i}$, and has a variant form $k n \bar{e}$ (a.o. attested in the Emsing tradition!) ${ }^{39}$, we may assume a variant form hle for OFri hli, making it unproblematic to assume that the form $<$ hleth $>$ comes from hlia.

\section{A few Old West Frisian lexicological probems}

The OWFri corpus (of forms with \#hR-) also holds some lexicological problems, though not as much as the OEFri.

First, there is OFri hreggisbenbreke, found in U, A and J. In D we find <hregbenbreke $>$, and we may ask whether or not this form belongs to a different headword. The first question is whether the compound should be interpreted as hreg(gis)ben + breke, or as hreg(gis) + bennbreke. In fact, we find both solutions in Holthausen and Hofmann, namely hreg(g)bên 'Rückgrat (backbone; vertebral column)'40, and bênbreke 'Knochenbruch (breaking of a bone)' 41 . Moreover, when Holthausen adds a headword hreggisbên 'Rückgrat' in the section 'Berichtigungen und Nachträge', Hofmann corrects this to 'ein Knochen im Rücken (a bone in the back)' in the section 'Ergänzungsliste $^{142}$. All this means that in theory we might encounter something like $*<$ hreggisbenis benbreke $>$, as we do with <Quembenis benisbreke $>$ in $\mathrm{J}^{43}$. But we do not. What we do find in many of the fines is ben(is)breke plus a specification of where a bone is broken, followed by the fine to be paid, and we also encounter a form $<$ Benbreke thes rugghes $>/<$ Benbreke this regghis $>44$. All this points to a headword hreg(gis)-bēnbreke, meaning 'breaking of a bone in the back'. When the spine was broken to such an extent that paralysis (paresis) or deterioration of the senses ensued from this, there was a different term in OFri, namely wald (u)waxe(dede), e.g. <That waldwaxa bote thet is xxvj enghelscha $>$ in $J, X X I, 100$. It should be noted that this is the same

39 W. L. van Helten, Altostfriesische Grammatik, Leeuwarden 1890, 134/5.

40 Holthausen and Hofmann (see n. 15), 6 (hregbên) and 47 (hreggbên).

41 Holthausen and Hofmann (see n. 15), 6.

42 Holthausen and Hofmann (see n. 15), 140 and 185 resp. It should be clear by now that consulting this dictionary is at times rather tiresome, and that we are in dire need of a new OFxi dictionary.

43 J,XXI,49; W. J. Buma en W. Ebel (as n. 22) 410.

$44 \mathrm{~J}, \mathrm{XXII}, 113$ and $\mathrm{J}, \mathrm{XXIV}, 48$. 
text in which we also find the attestation <reggisbenbreke $>45$.

A cranberry morph $<$ hnaw $>$ can be found in one of the charters ${ }^{46}$. In my opinion we are dealing with the only OFri rendition of PGmc. *hnaww- 'exact, precise, narrow, tight' 47 .

It is a bit doubtfull whether hros '(war)horse' (only found spelled $<$ ros $>$ ), is really OFri, or whether it is a loanword, since we also have OFri hers 'horse'. As we shall see below, the fact that I chose to include these forms does not alter the analysis much.

\section{The Old East Frisian evidence}

The OEFri corpus yields a total of 357 forms with \#hR-, i.e. $\pm 13 \%$ of the total OFri evidence. Their distribution over the different spelling variations can be seen in the following table. ${ }^{48}$

\begin{tabular}{|l|l|l|l|l|l|l|}
\hline & $\langle(\mathrm{h}) \mathrm{R}\rangle$ & $\langle\mathrm{hR}\rangle$ & $\langle\mathrm{R}(\mathrm{h})\rangle$ & $\langle\mathrm{Rh}\rangle$ & $\langle\mathrm{R}\rangle$ & tot: 357 \\
\hline $\mathrm{l}$ & & 122 & & 9 & 15 & 146 \\
\hline $\mathrm{n}$ & & 12 & & 3 & 5 & 20 \\
\hline $\mathrm{r}$ & 8 & 56 & 1 & 11 & 115 & 191 \\
\hline
\end{tabular}

The notations $<(h) R>$ and $<R(h)>$ denote the hypercorrect forms which appear in the charters and in the Emsing tradition, in the 15th century (see appendix). This means that $\langle\mathrm{hr}\rangle$ or $\langle\mathrm{rh}\rangle$ was written where etymologically $\langle r\rangle$ should occur.

The first thing that should be noted is that the cluster \#hr-is already declining fast, whilst \#hl- and \#hn- are 'still going strong'. Approximately $65 \%$ of the correct forms with \#hr-is spelled $\langle r\rangle$, and this trend is already detectable in the oldest manuscripts $(B 1, H 12, R)$.

In the OEFri corpus the following hypercorrect forms (only with \#hr-) appear; bi(h)rëda, (h)rēde, (h)rēdieva, (h)rēka, (h)reknia, (h)rokk (also see the appendix). The first ones are found in one of the OEFri charters, i.e. stemming from the province of Groningen, dated 1397. The last are from E2 and E3 (both dated 1450). Apparently the cluster \#hr-was barely audible by that time, and mistakes were rather easy to make (though not on a large scále).

$45 \mathrm{~J}, \mathrm{XX1}, 48$.

46 O2,57,19: original, dated 1463.

47 Cf. J. de Vries, Altnordisches etymologisches Wörterbuch, Leiden 1961, 246.

48 I will not give tables for every single manuscript; but I will discuss the results of each manuscript in more detail in section 10 of this article. 


\section{The Old West Frisian evidence}

The OWFri evidence amounts to a total of 2435 tokens, i.e. $87 \%$ of the OFri evidence. The charters alone yield 1485 tokens, i.e. $53 \%$ of the complete OFri evidence or $61 \%$ of the OWFri material. This corpus is also largely filled with tokens of a relatively small number of types: hlīa 2 (659 tokens), hlest 1 (115 tokens), hlūd 1 (100 tokens), hröra (100 tokens), hrōpa (80 tokens) and hreplik (50 tokens) (see appendix) make up $72 \%$ of the evidence from the charters. The spelling forms are given in the table below.

\begin{tabular}{|c|c|c|c|c|c|c|c|c|c|c|}
\hline & $(\mathrm{h}) \mathrm{R}$ & $\mathrm{hR}$ & $\mathrm{hh}$ & $\mathrm{hhR}$ & $\mathrm{Rh}$ & $\mathrm{RhR}$ & $\mathrm{R}(\mathrm{h})$ & $\mathrm{gR}$ & $\mathrm{R}$ & 2435 \\
\hline $\mathrm{l}$ & 30 & 1184 & 1 & 1 & 4 & 1 & 2 & 2 & 276 & 1501 \\
\hline $\mathrm{n}$ & & 4 & & & & & & & & 4 \\
\hline $\mathrm{r}$ & 31 & 1 & & & & & & & 898 & 930 \\
\hline
\end{tabular}

We can see that $\langle\mathrm{hl}\rangle$ is still continuing its slow decline. All the exotic spellings, $\langle\mathrm{hh}\rangle,\langle\mathrm{hhl}\rangle,\langle\mathrm{lhl}\rangle$ and $\langle\mathrm{gl}\rangle$, stem from the charter material. We should also note for now that $<R h>$ only is attested for the cluster \#hl-in OWFri. Words with the cluster \#hn-are very poorly attested (4 in all).

Where \#hr-is concerned, however, we see a radical break with the OEFri tradition: except for one strange attestation ${ }^{49}$, we find no spelling $\langle\mathrm{hr}\rangle$ or $\langle\mathrm{rh}\rangle$, but only $\langle\mathrm{r}\rangle$ and hypercorrect forms with $<(h) r>$. This means that the cluster \#hr-died out along with OEFri. It remains a mystery why only hypercorrect forms with $<$ (h)r $>$ were written. The only common feature many but not all of them show is long $\bar{e}$ as rootvowel. All have a long root (either (C)CVVC or (C)CVCC; see appendix).

We not only find hypercorrect forms with $\langle(h) r>$, we also for the first time encounter hypercorrect forms with $\langle(\mathrm{h}) \mathrm{l}\rangle$ in the OWFri corpus (see the appendix and below). This must mean that like \#hr-in OEFri, \#hl- was no longer clearly perceivable and mistakes were made. The first hypercorrect forms either stem from $\mathbf{J}$ if this manuscript is to be dated 1464 , or from a charter from $1473^{50}$.

49 Namely <weer hrapen>< OFri wicherhrōpa 'to revoke, retract' in 01,76,9 from an original dated 1439. Not only is <hr peculiar, so is the vowel <a>. In all other forms we find $<\mathrm{e}>$ or $<0>$ in the past participle $(\mathrm{pp})$ of this verb.

$50<$ hleste> $01,236,79$, original dated 1473 . 


\section{A chronology of the process}

The difficulty with plotting the chronology of the process of loss of OFri $h$ in initial consonant clusters is that for the OEFri evidence the axes time and space overlap. By this I mean that e.g. the sudden increase in writing $\langle\mathrm{hr}\rangle$ in favor of $\langle\mathrm{r}\rangle$ in E123 could be dialectal, but could just as well be a last upsurge of conscientious orthography just before the cluster died out. Because of the rather sparse evidence from this time it is hard to tell which explanation is the right one.

The oldest OEFri manuscripts date from the end of the 13th century: $\mathrm{B} 1$ and $\mathrm{H} 12^{51}$. Here the decline of the cluster $\# h R$ - has already begun. $\mathrm{B} 1$, said to be the oldest manuscript, shows $4 \mathrm{x}<\mathrm{hl}>$ against $2 \mathrm{x}<\mathrm{lh}>$ (no $<\mathrm{l}>$ ), and $1 \mathrm{x}<\mathrm{rh}>$ against $3 \mathrm{x}<\mathrm{r}>$ (no $<\mathrm{hr}>$ ). Since $\mathrm{H} 1$ is a copy of $\mathrm{H} 2$, we find almost exactly the same orthography: $13 \mathrm{x}\langle\mathrm{hl}\rangle, 5 \mathrm{x}\langle\mathrm{l}>$; $\mathrm{H} 2$ has $12 \mathrm{x}<\mathrm{hr}>, 1 \mathrm{x}<\mathrm{rh}>$ and $12 \mathrm{x}<\mathrm{r}>$, against $\mathrm{H} 111 \mathrm{x}<\mathrm{hr}>$ and $13 \mathrm{x}$ $<r>52$. As mentioned, our oldest fragment of OFri is probably the Psalm glosses (1200?). They show $1 \mathrm{x}<\mathrm{r}\rangle$.

Immediately after these manuscripts follow R1 and the fragments R3 and $R 4$, all dated to 1300 . Here we find roughly the same pattern: $R 1$ has $7 \mathrm{x}\langle\mathrm{hl}\rangle, 4 \mathrm{x}<\mathrm{lh}\rangle ; 4 \mathrm{x}\langle\mathrm{hr}\rangle, 22 \mathrm{x}\langle\mathrm{r}$. R3 has $1 \mathrm{x}\langle\mathrm{l}\rangle, 2 \mathrm{x}\langle\mathrm{r}\rangle$, and $\mathrm{R} 4$ has $3 \mathrm{x}<\mathrm{r}\rangle$. Then come R2 (1327); 22x $\left\langle\mathrm{hl}>, 11 \mathrm{x}\langle\mathrm{r}\rangle{ }^{53}\right.$, and B2 (1345); $6 \mathrm{x}<\mathrm{hl}>, 1 \mathrm{x}<\mathrm{lh}>, 3 \mathrm{x}<\mathrm{rh}>, 1 \mathrm{x}<\mathrm{r}>$.

By the end of the 14th century we find the OEFri charters (1385 and 1397) which contain forms with \#hR-. They show $2 \mathrm{x}\langle\mathrm{hl}\rangle, 6 \mathrm{x}\langle(\mathrm{h}) \mathrm{r}\rangle$, $3 \mathrm{x}\langle\mathrm{hr}\rangle, 2 \mathrm{x}\langle\mathrm{r}\rangle$. Note that for the first time do we encounter hypercorrect forms. On the whole we see that all clusters are already declining at the beginning of the OFri tradition, and because of the small body of evidence it is hard to detect a dialectal trend.

Now we get to the 15th century, beginning with E1, dated to 1400 (but uncertain). E1 shows $13 \mathrm{x}<\mathrm{hl}\rangle, 2 \mathrm{x}<\mathrm{l}>, 11 \mathrm{x}<\mathrm{hr}\rangle, 7 \mathrm{x}<\mathrm{r}\rangle^{54}$. E23 and $F$ follow, all dated to ca. 1450. E2 shows: $5 \mathrm{x}\langle\mathrm{hl}\rangle, 2 \mathrm{x}\langle\mathrm{lh}\rangle, 2 \mathrm{x}$ $<\mathrm{l}>, 3 \mathrm{x}<\mathrm{hr}\rangle, 3 \mathrm{x}<\mathrm{rh}\rangle, 1 \mathrm{x}<\mathrm{r}(\mathrm{h})>, 3 \mathrm{x}<\mathrm{r}>55$. E3 shows: $11 \mathrm{x}<\mathrm{hl}>, 2 \mathrm{x}$ $<(h) r\rangle, 9 x<h r>, 3 x<r>56$. F shows: $26 x<h l>, 3 x<h r>, 3 x<r h>, 32 x$

51 Because of the small number of attestations of \#hn- (a total of 24 for the entire OFri corpus), the analysis of the process for this cluster is rather difficult, and I shall for the most part leave it outside the discussion.

52 H12: $1 x<h n>, 1 x<n h>, 1 x<n>$.

$531 \mathrm{x}<\mathrm{hn}>$.

$545 \mathrm{x}<\mathrm{hn}>$.

$552 \mathrm{x}<\mathrm{hn}>, 1 \mathrm{x}<\mathrm{nh}>, 3 \mathrm{x}<\mathrm{n}>$.

$56 \mathrm{~lx}<\mathrm{hn}>$. 
$<r>57$. It is tempting to interpret the material from the 15 th century in such a way that the Emsing dialect shows a better position of <hr $>$ against $<r>$-spellings than the other dialects do.

With these manuscripts, in the middle of the 15th century, the OEFri tradition comes to an end. Some $90 \%$ of attestations still show $<\mathrm{h}>$ (either $\langle\mathrm{hl}\rangle$ or $\langle\mathrm{lh}\rangle$ ) in the cluster \#hl-. As mentioned, attestations of the cluster \#hn- are rare. We encounter 20 forms, of which $75 \%$ show $<\mathrm{hn}>$ or $<\mathrm{nh}>$, and $60 \%$ show $<\mathrm{hn}>$. As for the cluster \#hr-, only some $36 \%$ of attestations still show $\langle\mathrm{h}\rangle$ (either $\langle\mathrm{hr}\rangle$ or $\langle\mathrm{rh}\rangle$ ).

In the Emsing tradition $<\mathrm{h}>$ is best preserved in the cluster \#hr-, but we also encounter hypercorrect forms here, which may indicate a period of confusion, where $\langle\mathrm{h}\rangle$ was no longer clearly audible. Perhaps because of some conservative trend (concomitant with the character of the codices?) the scribes started to spell $<\mathrm{h}>$ more diligently, in the process of which hypercorrect forms were possibly created.

A little before the beginning of the 15 th century the OWFri tradition sets in, creating an overlap of some 50 years with the OEFri one. As mentioned, we can see a caesura with OEFri, for all attestations ${ }^{58}$ of the cluster \#hr-are spelled $<r>$ in OWFri. Moreover, we find some 30 spelling forms $\langle h r\rangle$, which are all hypercorrect.

Since the cluster \#hr-was reduced to $\# r$ - in OWFri, and we have only 4 attestations of the cluster $\# h n$ - (all spelled $<\mathrm{hn}>$ ), the OWFri corpus mainly informs us about the decline of the cluster \#hl-.

As I said in section 9, OWFri can be divided in three subgroups. The first subgroup, the legal codices c.s., shows a rather homogenous picture. As far as the process of reducing \#hl- to \#l-is concerned, they show only $<\mathrm{hl}>,<\mathrm{l}>$ and a few hypercorrect spellings (so no $<\mathrm{lh}>$ or any of the exotic variants given in the table in section 9). Neither does $<(h) r>$ occur. Here $91 \%$ of the forms of the cluster \#hl- is written $<\mathrm{hl}>$.

In the following table, I have plotted the evidence from all OWFri sources which are datable with any certainty. This means that $J$ and Fs have been left out. Only the spellings $<\mathrm{hl}>$ and $<\mathrm{l}>$ are considered.

\begin{tabular}{|l|l|l|l|l|}
\hline $01234+()$ & $\langle\mathrm{hl}\rangle$ & $\langle\mathrm{l}$ & total & $\%<1\rangle$ \\
\hline 1378 & 1 & & 1 & 0 \\
\hline 1405 & 1 & & 1 & 0 \\
\hline
\end{tabular}

$571 \mathrm{x}<\mathrm{hn}>$.

${ }^{58}$ Except for the single attestation with correct $<$ hr $>$ mentioned in section 9 . 


\begin{tabular}{|l|l|l|l|l|}
\hline 412 & 2 & & 2 & 0 \\
\hline 421 & 1 & & 1 & 0 \\
\hline 431 & 1 & 1 & 2 & 50 \\
\hline $440-9(\mathrm{BT})$ & 4 & & 4 & 0 \\
\hline $450-9$ (E4) & 29 & 6 & 35 & 17.1 \\
\hline $460-9$ & 34 & 4 & 38 & 10.5 \\
\hline $470-9(\mathrm{U})$ & 146 & 11 & 157 & 7 \\
\hline $\begin{array}{l}480-9 \\
\text { Q,D,FR) }\end{array}$ & 217 & 8 & 225 & 3.5 \\
\hline $490-9(\mathrm{SR}, \mathrm{FB})$ & 127 & 14 & 141 & 9.9 \\
\hline $\begin{array}{l}500-9 \\
\text { (,A,P,LS) }\end{array}$ & 260 & 74 & 334 & 22.2 \\
\hline $510-9(\mathrm{SR})$ & 149 & 64 & 213 & 30 \\
\hline $\begin{array}{l}520-9 \\
\text { R(LM,EJ,FB) }\end{array}$ & 94 & 44 & 138 & 31.8 \\
\hline $530-8(\mathrm{FB})$ & 50 & 17 & 67 & 25.3 \\
\hline $540-8$ & 17 & 13 & 30 & 43.3 \\
\hline $550 / 1(\mathrm{FB})$ & .0 & 3 & 3 & 100 \\
\hline $573(=\mathrm{FB})$ & 0 & 1 & 1 & 100 \\
\hline
\end{tabular}

However clearly we can see the decline of the spelling $<\mathrm{hl}>$ or the rise of the spelling $<\mathrm{l}>$ over the years, the final stage still seems to come to an end rather abruptly. Because we do not have any other OFri material to tell us what happened after 1550 , we must assume that \#hl-became \#l-around that time.

We do, however, have two sources which are not considered OFri, and which have been written in the second half of the 16th century. They are the collection of aphorisms made by Reyner Bogerman (1542 and 1551) and the rekenboeck off memoriael (1569-1573), a housekeeping book of farmer Rienck Hemmema of the village of Hitsum (a few $\mathrm{km}$ south of the city of Franeker in the Dutch province of Friesland). In these sources only $<\mathrm{l}>$ spellings are found ${ }^{59}$. It is therefore safe to assume that \#hl-died out around 1550.

As mentioned, the OWFri material yields the first hypercorrect $\langle\mathrm{hl}>$ spellings. They can be seen as indicators of the decline of the realisation of $h$ in the cluster \#hl-. They are found in $J$ (either dated 1464 or 1530 ), and then in charters from $1473,1488,1491,1492,1494$,

59 T. J. de Boer, 'Reyner Bogerman's Friesche rijmspreuken', in: De Vrije Fries 19 (1900), 205-279; 268-269 and P. Gerbenzon (ed.), Rienck Hemmema. Rekenboeck off memoriael (Estrikken 14), Groningen 1956, 74. 
$1504,1507,1520,1521,1525$. We also find them in A (dated 1500) and LM (dated 1525). This means that we find them some 75 years before the cluster \#hl-died out.

When we look back at the OEFri evidence and the disappearance of the cluster \#hr-, we find the first hypercorrect spellings in a charter dating from 1397, and then again in E23, dating from ca. 1450. This means that we find hypercorrect spellings some 50 years before $\#$ hrdied out.

The two processes seem rather comparable and logical. What is, however, strange and atypical are the hypercorrect $<$ hr $>$-spellings in OWFri, some 30 in all. We find them in $1410,1439,1467,1473$, $1475,1476,1478,1479,1481,1484,1488,1489,1490,1494,1495$, 1497,1498 and 1544 . This means that the bulk stems from the period 1470-1500. When we look at the appendix, we see that a number of them, like $(b i)(h) r e \bar{d} a$, brēde and hrêka, are found in both the OEFri and the OWFri charters. This might point to a common tradition. I have no explanation for this phenomenon.

To sum up, we have seen that \#hr-died out together with OEFri, around 1450, and that the cluster \#hl-died out together with OWFri, around 1550 . The cluster \#hn-probably disappeared a little before the end of \#hl-, although the evidence is too scarce to say anything definite about this.

The decline of all clusters had already set in when OFri began to be written down. From the evidence gathered by Lutz, we know that in English the disappearance of $\# h R$ - took place over a period of some 300 to 400 years $^{60}$. If we are allowed to extrapolate these findings to the Frisian situation, this would mean that here the decline of \#hr- had set in somewhere between 1050 and 1150, and that of \#hl- somewhere between 1150 and 1250 .

\section{Phonetic analysis}

In this last section, I will try to analyse the process of the loss of OFri $h$ in initial consonant clusters on a phonetic level. What were the phonetic characteristics of the sounds concerned, and how did the process take place phonetically?

It is commonly acknowledged that $h$ is a stage in a natural weakening process. PGmc \#hR- developed out of Proto Indo-European (PIE)

60 A. Lutz, Phonotaktisch gesteuerte Konosonantenveränderungen in der Geschichte des Englischen, Tübingen 1991, 29. 
$\# k R$ - or \#kVR-, as part of the First Germanic Soundshift, which made $\mathrm{PIE} / \mathrm{k} />\mathrm{PGmc} / \mathrm{x} \sim \mathrm{h} /{ }^{61}$. Note that $[\mathrm{h}]$ was an allophone of the phoneme $/ x /$, and never reached phonemic status. It is assumed that since $\mathrm{PGmc}$, \#/x/R- was realised \#hR-62.

Although $h$ is an allophone of $/ \mathrm{x} /$, it is not really a velar. In fact [h] is a rather elusive sound, often described as a voiceless glottal fricative. What makes it so difficult to characterize is that it lacks oral articulation or gesture. In this way it is akin to the glottal stop [2]. In fact, both have been analysed by Lass, who calls them the minimal voiceless fricative ([h]) and the minimal voiceless stop ([?] $)^{63}$. In OFri we occasionally encounter $<\mathrm{h}>$ for [1], as in sancte Michaheles di and israheliske ${ }^{64}$. We also find a few instances of hāga for āga 'to own' 65 and halfte for alfte eleventh'66.

Based on the research done by Lutz ${ }^{67}$ for the decline of [h] in different phonotactic positions in English, we can sketch a number of different scenarios for the loss of OFri $h$ in $\# h R-$ :

1. \#hR- > \#hR- > \#R $\mathrm{R}_{-}>\# \mathrm{R}-$;

2. \#hR- $>$ \#R[-voice $]_{-}>\# \mathrm{R}-$;

3. \#hR- > \#hR[+ velar]- > \# [+ velar $>\# h R-$.

Scenario 1 means that while [h] disappeared, $R$ first became preaspirated, then aspirated, and then became normal $\mathbf{R}$ again. This scenario is supported by the Modern Icelandic realisation of \#hR-and by spellings $\langle\mathrm{lh}\rangle,\langle\mathrm{nh}\rangle$ and $\langle\mathrm{rh}\rangle$, which we also find in OFris.

Scenario 2 means that $[\mathrm{h}]$ transferred its voicelessness to $R$ while disappearing, and that $R$ eventually became voiced again. This scenario is only supported by the Modern Icelandic realisation of \#hR-, but is not found in spellings, except that it seems a natural consequence of

61 See also the weakening hierarchy in: H. H. Hock, Principles of Historical Linguistics, Berlijn etc. 1986, 83.

62 W. G. Moulton, 'The Proto-Germanic Non-syllabics (Consonants)', in: F. van Coetsem en H.L. Kufner (eds.), Toward a Grammar of Proto-Germanic, Tübingen 1972, 141-173, 143.

63 R. Lass, 'On the Phonological Characterization of [2] and [h]', in: R. Lass, English Phonology and Phonological Theory. Synchronic and Diachronic Studies, Cambridge 1976, 145-167, 154.

64 D. Boutkan, A concise grammar of the Old Frisian dialect of the first Riustring manuscript (NOWELE Suppl. 16), Odense 1996, 14.

65 Ibid.

66. B. Sjölin (ed.), Die 'Fivelgoer' Handschrift. II (OTR 13) The Hague 1975, 7.

67 Lutz (as n. 60) 29-37. 
aspiration, which would mean that scenarios 1 and 2 are intrinsically linked, and that spellings $<\mathrm{lh}\rangle,<\mathrm{nh}\rangle$ and $<\mathrm{rh}>$ aiso inform us about the voicelessness of $R$.

Scenario 3 means that $[\mathrm{h}]$ transferred its 'velarity' to $\mathrm{R}$ while disappearing. We should, however, note that PGmc, OE and OFri $l$ and $r$ were probably more velar than is usually thought. Not only certain soundchanges in $\mathrm{OE}$ point to this (eg. breaking before $-\mathrm{IC}$ - and $-\mathrm{rC}$ together with other velar consonants ${ }^{68}$ ), but also OFri auld for ald 'old' and the realisation of $/ 1 /$ in the modern dialect of Hindelopen ${ }^{69}$ and in standard ModFri. If it turned out that the velar character of $r$ and $l$ was retained better in English and Frisian than in the other Gmc languages, this could partly explain why English and Frisian were the last to lose $h$ in $\# h R$ -

I think, however, that, like Lutz did for English, we must assume that phonetically the loss of OFri $h$ in \#hR-can best be seen as a combination of scenarios 1 and 2, concomitant with the Modern Icelandic pronunciation.

\section{Appendix: glossary \\ $+=$ Not in Holthawsen and Hofmann, Altfriesisches Wörterbuch \\ vb. $=$ verb}

hI

*hlada 'load (vb.)' (better *hletha or *hleda) [O24]

hladder 'ladder' [H12; A]

brondhladder 'fure ladder' [O2]

hladdergong

'space to put the ladder on the roof' [E3]

hlakkia

hläpa

'laugh (vb.)' [D;J;LM]

'walk, go, run, jump, leap (vb.)' [H12; E123;

R1; F; OO; A; J; FR; RO; D; U; O12]

tbihlāpa 'amount, cost (ṿb.)' [SR; O34]

gadurhlāpa 'come together (vb.)' [OO]

+londhlēper 'vagabond' [SR]

tōhlāpa 'walk toward (vb.)' [R1; E1; F; J]

uphlāpa 'arise, happen (vb.)' [H12; B12; E3; F; A; U; D; RO; FS]

68 See R. Lass, 'Velar / $/$ / and the History of English', in: M. Davenport et al. (eds.), Current Topics in English Historical Linguistics, Odense 1983, 67-94 and R. Runge, Proto-Germanic $/ r /$. The Pronunciation of $/ r /$ throughout the History of the Germanic Languages, Göppingen 1974.

${ }^{69}$ B. de Boer, Studie over het dialect van Hindeloopen, Assen 1950, 53. 


\begin{tabular}{|c|c|c|}
\hline \multirow{4}{*}{ hlēda } & +urhlāpa & 'walk (over something) (vb.)' [O1] \\
\hline & & ‘sound (vb.)’ [F; J; D] \\
\hline & bihlëda & 'make known, public (vb.)’ [RO; A; O2] \\
\hline & urhlett & 'notorious' [A; U; RO] \\
\hline \multicolumn{2}{|c|}{ hlēdere } & $=$ hladder \\
\hline & '(loaf of) bread' [J] \\
\hline & hlemm & 'blow, strike' [B12] \\
\hline & biärhlemm & 'pouring beer over someone' $[\mathrm{H} 12 ; \mathrm{R} 3]$ \\
\hline \multicolumn{2}{|c|}{ hlenbedd } & ‘sick bed’ [E2] \\
\hline \multicolumn{2}{|c|}{ hlenzene } & ‘crookedness' [B12] \\
\hline \multicolumn{2}{|c|}{-hlèp } & 'leap, walk, jump' \\
\hline & bekhlēp & 'jumping on someone's back' [H12; E123] \\
\hline \multicolumn{2}{|c|}{ hlest 1} & $\begin{array}{l}\text { ‘tax, burden’ [H12; RO; J; FB; O1234; A; P; } \\
\text { SR] }\end{array}$ \\
\hline & tahlest & 'extra tax, burden' [012] \\
\hline & +tziarkhlest & 'church tax' [O2] \\
\hline \multicolumn{2}{|c|}{ +unhlest 1} & $\begin{array}{l}\text { 'non-burden; profit' (in: hlest ende onhlest) } \\
\text { [0123] }\end{array}$ \\
\hline & urhlest & 'annoyance, nuisance' [D; O234; SR] \\
\hline hlest $2^{\text {urhlest }}$ & & 'attention' [U; J; D; BT] \\
\hline \multicolumn{2}{|c|}{ unhlest 2} & 'commotion, cheering' [F; J; U; D; FS; O2; SR] \\
\hline \multirow[t]{3}{*}{ hlesta } & 1 & 'tax (vb.)' [RO; O2; SR] \\
\hline & bihlesta & 'tax (vb.)' [O124; SR; RO] \\
\hline & +unbihlest & 'untaxed' [J; 012] \\
\hline \multicolumn{2}{|c|}{ hlestich } & 'taxing, urgent' [RO; O1; LR] \\
\hline \multicolumn{2}{|c|}{ hlestigia } & 'hinder, annoy (vb.)' [RO; O2] \\
\hline & & 'hinder, annoy (vb.)' [RO; O1234] \\
\hline \multicolumn{3}{|c|}{ tunbihlestiget ${ }^{6}$ unhindered, unburdened'? [O2] } \\
\hline \multicolumn{2}{|c|}{ +hlestinge } & 'tax'? [O2; SR ] \\
\hline \multirow[b]{2}{*}{ hli } & +bihlestinge & 'tax'? [02] \\
\hline & & 'protection' [E1; F; J; U; D] \\
\hline \multirow{5}{*}{$\begin{array}{l}\text { hlia } \\
\text { hlia } 2\end{array}$} & 1 & 'cover like a blanket (vb.)’ $[\mathrm{F} ; \mathrm{J}]$ \\
\hline & & $\begin{array}{l}\text { 'say, declare (vb.)’ [R12; F; J; U; D; RO; A; } \\
\text { FS; O1234; SR; FB] }\end{array}$ \\
\hline & bihlia & $\begin{array}{l}\text { 'declare, confess (vb.)' [R2; F; U; A; RO; FS; } \\
\text { O1234; SR; LS] }\end{array}$ \\
\hline & inhlia & 'declare (vb.)' [RO] \\
\hline & +urhlía & 'accuse (vb.)' [J] \\
\hline \multirow[t]{2}{*}{ hlid } & & 'lid, eye-lid' [H12; R1; E123; F; J; U] \\
\hline \multirow{2}{*}{\multicolumn{2}{|c|}{ aghlid }} & ‘eye-lid' [E13; J; U; D] \\
\hline & & ‘cover, lock (vb.)’ $[\mathrm{F}]$ \\
\hline \multicolumn{2}{|c|}{ hligene } & 'declaration, order' [B12; R12] \\
\hline \multicolumn{2}{|c|}{ hliinge } & 'declaration' [A; RO; SR; O124] \\
\hline
\end{tabular}




\begin{tabular}{|c|c|c|}
\hline \multirow{5}{*}{$\begin{array}{l}\text { hlot } \\
\text { hlöth } \\
\text { hlotia } \\
\text { hlūd } 1\end{array}$} & \multirow[t]{2}{*}{ bihlïinge } & 'declaration' [RO; O2; FB] \\
\hline & & 'lot' [F; J; D; RO; O2; LR] \\
\hline & & 'group, company of people' [B 12] \\
\hline & & 'draw or cast lots (vb.)' [RO; FS; O124] \\
\hline & & $\begin{array}{l}\text { ‘sound, tenor’ [H12; F; E1; J; U; D; A; RO; } \\
\text { O1234; SR; LS; FB; LR; EJ] }\end{array}$ \\
\hline & mēnhlūe & 'common rumour' [RO] \\
\hline & +quādhlūich & 'having a bad reputation' [A] \\
\hline hlūd 2 & tunblūd & $\begin{array}{l}\text { unspeakable thing [FR] } \\
\text { 'loud' [J; U; D;A;RO] }\end{array}$ \\
\hline hlūda & & 'sound (vb.)' [U; RO; O2; FR] \\
\hline & tbihlūda & 'accuse (vb.)' [RO] \\
\hline -hlūdig & & 'accuse (vb.)' \\
\hline & bihlūdigia & 'accuse (vb.)' [RO] \\
\hline ter & & 'pure, clean' [U; RO] \\
\hline
\end{tabular}

hn-

+hnāw

'exact, precise, narrow, tight' [02]

hnekka

'neck' [H12; E123; F; U]

hnetze

'hood, cap; bonnet (worn by women)' [H12;

E12]

hniga

'bow, bend (vb.)' [R2; E2; J; A]

hr-

hramkorf

-hrē

hrēklēth hrēlīk

hrēè(s)rāf

hredda

ahredda

hredde

href

hreg

hregbreka

hofhreg

londhreg

hreggisbēnbreke

hreglemithe

hregskerd

hregstivenge

'fishing net, fish trap' [O2]

'corpse'

'outer garment of a woman' [H12]

'corpse' [H12]

'tomb robbery, robbing of a corpse' [H12; F; J;

$\mathrm{D} ; \mathrm{U} ; \mathrm{A}]$

'save (vb.)' [E23; F; J]

'save (vb.)' [E2]

'secure, undisputable' [F]

'diaphragm, midriff' [J] also hrif 1

'back, spinal column' [E3; F; J; A; D; U; O23;

SR; FR]

'wall round the churchyard?' [J]

'wall (used as border of a plot)' [O2]

'break the spinal column (vb.)' [F]

'breaking of a bone in the back' [J; D; U; A]

'paralysis of the back' [R1]

'wounding of the back' [E1]

'stiffness of the back' [F] 
hreid

threidblok

+hreidekker

threidkomp

threidlond

threidmere

threidpōl

hreil +lifhreid

hreilbende

hreilmerk

hrekka

hrembende

hrena

hrene 1

hrēne 2

hrēnichēd

hreppa

bihreppa

unbihrepped

hreplik

tunhrēne

hreppinge

unhreplik

tbihreppinge

hrēra

hrespa

-hrether

midhrether

hrif 1

inhrif

midhrif

hrīf 2

hring

hringbende

āghring

thringmūre

hriowa

hrīs

bihriōwe

bihriōwsigia

hrither 'reed' [F; O1234; LM]

'plot of reed' [O2]

'acre of reed' [O2]

'plot of reed' [SR]

'plot of reed' [O124]

'lake or pool in which reed grows' [0124]

'lake or pool in which reed grows' [012]

'reed for sustenage; living reed'? [03]

'textile, robe' [E1; OO; J; D]

'iron fetter' [R1]

'value of a mark in linnen' $[\mathrm{H} 12 ; \mathrm{R} 123 ; \mathrm{E} 13 ; \mathrm{F}$;

$\mathrm{D} ; \mathrm{J}]$

'tear (vb.)' [H12]

'fetter' [H12; E123]

'smell (vb.)' [R12; E1]

'scent' [H12; R1; E12; F]

'pure, clean' [R1; U; A; BT]

'unpure, dirty' [U; A]

'purity' [U;A]

'touch, move (vb.)' [F; OO; P; O13; SR]

'move (vb.)' [F]

'untouched' [B12]

'movable' [U; A; P; RO; O1234; SR]

'immovable' [U; A; P; RO; O124; SR]

'touch' [012]

'story, account' [RO]

'stir, move (vb.)' [E123]

'tear, pull (vb.)' [O12]

'midriff'

'midriff' [R124; F]

$=$ href

'intestines' [H12; R12; E1; F]

'midriff' [F]

'rake' [F]

'ring, circle' [F; OO; D; O1234; SR]

'eye socket' [H12; E23]

'fetter' (see also hrembende) [H12; F]

'ring-wall' [O4]

'mourn, repent (vb.)' [J; D; A; O2]

'mourning' [RO]

'mourn, repent (vb.)' [U; A; RO]

'osier, sprigs' [RO]

'cattle'; also: hrider, rēther, rēder, hrinder [H12;

R1; E13; F; J; U; D; O13; SR] 
tenterhrither 'one-year-old cow' [O2; SR]

-hrithere

+ twinterhrither 'two-year-old cow' [O3; SR]

hritherskett

midhrithere

hrivia

hrōf

hröft

+nachthrōft

tiānūthrōft

wēpinhrōft

hrōpa

tonkrōpa

bihrōpa

+ofhröpa

t tōhrōpa

tuphrōpa

üthrōpa

-hrōpere

witherhrōpa

hrōpinge

tōhrōpere 'summoner, crier' [023]

'calling, summoning' [O4]

bihrōpinge 'convocation' [U; P; RO; A; O124; FB]

thrōpjeld

witherhrōpinge 'revoking' [RO;O14]

hröpte

hrōra

'calling [O2]

'calling money'? [O3]

'calling' [O2]

ūthröpte 'alarm cry' [O2]

wēpenahrōpte 'alarm cry' [RO]

‘concern (vb.)’ [F; D; P; O1234; SR; LS; FB;

EJ]

bihrōra

+bihrōringe

'concern, move (vb.)' [PS; O123; SR]

+ forbihröra

tonhrōra

thrōrlik

+unhrōrlik

thros

hrümech

hrüta 'turmoil' [FB]

'allow (vb.)'? [O2]

'concern (vb.)'? [O1]

'movable' [O24; SR]

'immovable' [O2; SR; EJ]

'(war)horse' [J; D; U]

'sooty' [B12]

'rattle, gurgle (vb.)' [H12; E123] 
In Holthausen and Hofmann, but no attestation found:

tōhlotia

'draw the right lot (vb.)'

Hypercorrect spellings:
(h)lērd
'learned, wise' [LM]
(h)leppen
'corn measure' [J]
(h)lēra
(h)lest 3
'teach (vb.)' [LM]
(h)lesta 2
'last, final' [O1234]
(h)lëta
'pay, deliver (vb.)' [SR]
(h)lithwei
'let (vb.)' [A]
(h)lya
'sprain' [J]
'suffer? (vb.) [LM]
(h)rēda
'say, declare (vb.)' [O1]
(h)rēde bi(h)rēda
'prove, testify (vb.)' [E2]
'cash' in: mit hrëda jelde 'with cash money'
[OO;O1]
(h)rēdieva
'judge' [E3]
(h)rēd
'council, college' [O12; FB]
(h)rēka
'give, present, hand over (vb.)' [OO; O123]
(h)reknia
wither(h)rēka 'give back (vb.)' [O1]
(h)risa
'compute, count (vb.)' [OO]
(h)rokk
'arise (vb.)' [O1]
quit(h)lēta
+üt(h)lēda ${ }^{70}$
'skirt' [E3]
'acquit, let go (vb.)' [A]
'bury (vb.)', cognate to: ütlèdinge 'burial' [O2]

70 Uncertain: the only attestation, <uthleed $>$ might be analysed as $u t h+$ leed. 